This page intentionally left blank 


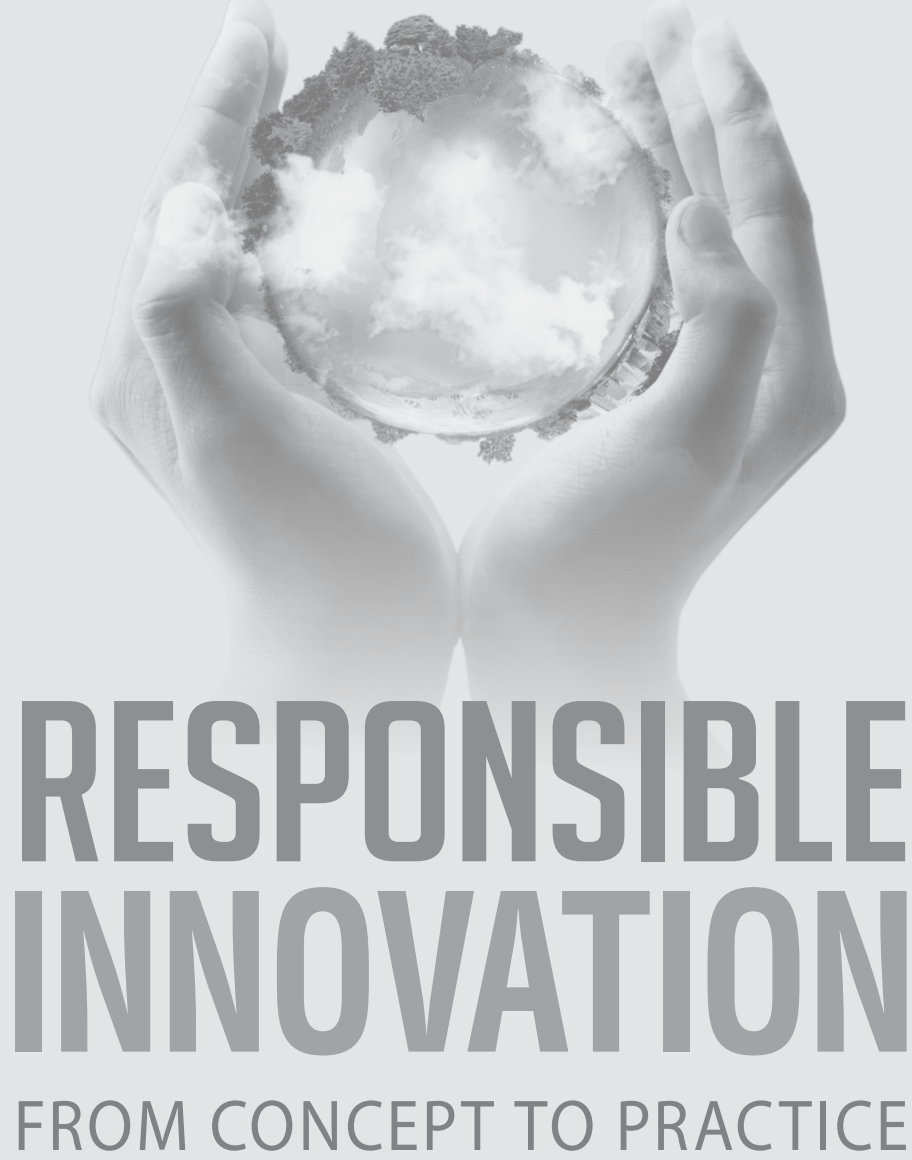

\section{Xavier Pavie}

ESSEC Business School, France

Victor Scholten

University of Technology, The Netherlands

Daphné Carthy

ESSEC Business School, France 
Published by

World Scientific Publishing Co. Pte. Ltd.

5 Toh Tuck Link, Singapore 596224

USA office: 27 Warren Street, Suite 401-402, Hackensack, NJ 07601

UK office: 57 Shelton Street, Covent Garden, London WC2H 9HE

\section{Library of Congress Cataloging-in-Publication Data}

Pavie, Xavier, 1973-

Responsible innovation : from concept to practice / by Xavier Pavie (ESSEC Business School, France), Victor Scholten (University of Technology, The Netherlands) \& Daphné Carthy (ESSEC Business School, France).

pages $\mathrm{cm}$

Includes bibliographical references and index.

ISBN 978-9814525077

1. Technological innovations--Management. 2. Diffusion of innovations--Management.

3. Organizational effectiveness. I. Title.

HD45.P3925 2014

658.4'063--dc23

2013027367

\section{British Library Cataloguing-in-Publication Data}

A catalogue record for this book is available from the British Library.

Copyright $@ 2014$ by World Scientific Publishing Co. Pte. Ltd.

All rights reserved. This book, or parts thereof, may not be reproduced in any form or by any means, electronic or mechanical, including photocopying, recording or any information storage and retrieval system now known or to be invented, without written permission from the Publisher.

For photocopying of material in this volume, please pay a copying fee through the Copyright Clearance Center, Inc., 222 Rosewood Drive, Danvers, MA 01923, USA. In this case permission to photocopy is not required from the publisher.

In-house Editors: Sandhya Venkatesh/Dipasri Sardar

Typeset by Stallion Press

Email: enquiries@stallionpress.com 


\section{CONTENTS}

ABOUT THE AUTHORS ix

ACKNOWLEDGMENTS Xi

INTRODUCTION X xiii

1. THE EMERGENCE OF THE RESPONSIBLE INNOVATION CONCEPT 1

1. An Explanation of the Terminology . . . . . . . . . . . 1

2. Exploring the Notion of Responsibility . . . . . . . 5 5

a. Permeability between the private and public spheres . . . 6

b. The imperative of responsibility . . . . . . . . . 7

c. The responsibility of the citizen/individual . . . . . 8

d. Political responsibility . . . . . . . . . . . . . . . 9 9

e. Responsibility: Moral standards and ethics . . . . . . . . . 11

f. The responsibility of a firm . . . . . . . . . . . . . 13

g. The question of stakeholders . . . . . . . . . . . . . 14

h. Managers and responsibility . . . . . . . . . . . . . . 15

i. Managers and the multiplicity of responsibilities . . . . . 20

3. Is Responsible Innovation Derived from CSR? . . . . . . . . 23

a. A question of religion . . . . . . . . . . . . . 23

b. The conscience of businessmen . . . . . . . . . 25

c. The secularization of CSR . . . . . . . . . . 26

d. Sustainable development . . . . . . . . . . . . . . . . 28

4. The Understanding of Responsible Innovation . . . . . . . . 31

a. Linguistics . . . . . . . . . . . . . . . . . 35

2. THE UNCERTAIN NATURE OF THE INNOVATION ENVIRONMENT $\quad 37$

1. Deciding in the Unknown and Unknowable . . . . . . . . . 37

a. Losing control of innovations . . . . . . . . . . 37

b. An ambiguous life cycle . . . . . . . . . . . . 38 
2. Adapting Sustainable Development Concept to Address New Global Issues . . . . . . . . . . . . . . . . . . . . . . . 43

3. The Axes of Responsible Innovation . . . . . . . . . . . . . . 44

a. Question the solutions to develop in response to individual needs . . . . . . . . . . . . . . . . . . . 44

b. Monitor and manage the direct impacts of innovations . . 48

c. Consider the indirect consequences of innovations . . . . . 51

d. Cases for responsible innovation . . . . . . . . . . . 52

e. Constructing and de-constructing the innovation process . . . . . . . . . . . . 57

\section{A GLOBAL INTEGRATION OF RESPONSIBLE} INNOVATION INTO ORGANIZATIONS

1. Impact of Responsibility on the Innovation Strategy . . . . . 61

a. A new model for integrating responsible innovation into organizational strategy . . . . . . . . . . . . . . 61

b. Adapting responsible innovation to SME specificities . . . 62

2. Five Stages for Becoming a Responsible and Innovative Organization .................. 68

a. Stage 1: Comply with the law . . . . . . . . . . . 68

b. Stage 2: Anticipate future legal requirements . . . . . . . 69

c. Stage 3: Think the value chain as an ecosystem . . . . . . 70

d. Stage 4: Develop responsible products and services . . . . 72

e. Stage 5: Lead the change . . . . . . . . . . . . . . . 78

3. An Evaluation of Responsible Innovation . . . . . . . . . . . 86

a. Responsible innovation: A product and process dimension .................. . . 88

b. Success of responsible innovation . . . . . . . . . . . . . . 92

c. Key challenges associated with responsible innovation . . 94

4. From the Precautionary Principle to a Responsible Innovation

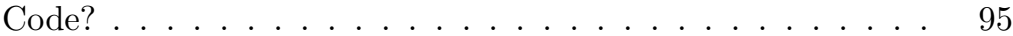

4. POLICY CASE FOR RESPONSIBLE INNOVATION 101

1. Interaction Between Regional Academe and SMEs . . . . . . 103

a. The role of knowledge spill-overs . . . . . . . . . . . . . . 103

2. Interaction Between SMEs from Different Sectors . . . . . . 105

3. Role of Transnational Interaction Between SMEs and

Technology Transfer Offices Located at Universities . . . . . 106

4. Key Responsible Innovation Policy Barriers . . . . . . . . . . 107 
5. RESPONSIBLE INNOVATION WITHIN RESEARCH AND EDUCATION

1. Research Grants . . . . . . . . . . . . . . . . . . . . . 112

2. Teaching Programs . . . . . . . . . . . . . . 114

a. Challenges for including responsible innovation . . . . . 115

b. Including responsible innovation at various levels of education systems f . . . . . . . . . . . . 118

\section{ACHIEVING RESPONSIBLE INNOVATION} AND OPTIMIZING ON PERFORMANCE

1. Applying Disruptive Innovation to the Social Sector . . . . . 125

2. Investing in Health Insurance . . . . . . . . . . . . 126

3. Investing in Education . . . . . . . . . . . . . 127

4. Investing in Economic Developments . . . . . . . . . . . 127

5. Integrating Responsibility: A Source of Innovation and Performance . . . . . . . . . . . . . 128

6. Critical Analysis of the Dow Jones Sustainable Index . . . . 129

7. The Importance of Governance . . . . . . . . . . . . . . 134

8. Responsibility Committees . . . . . . . . . . . . . . 137

9. Involving Citizens . . . . . . . . . . . . . . . . . . . . 138

10. The Case of the Nanocode . . . . . . . . . . . . . . . 139

11. Case Studies . . . . . . . . . . . . . . . . . . . . . . 141

a. Veja . . . . . . . . . . . . . . 141

b. Arup . . . . . . . . . . . . . . . . . . 142

c. Lend Lease . . . . . . . . . . . . . . . . . . . . 143

d. PepsiCo . . . . . . . . . . . . . . . . . 143

e. Skanska, UK . . . . . . . . . . . . . . . . . . . . . 144

f. Marks \& Spencer $(\mathrm{M} \& \mathrm{~S})$. . . . . . . . . . . . . . . 144

$\begin{array}{ll}\text { CONCLUSION } & 147\end{array}$

$\begin{array}{ll}\text { APPENDIX } & 151\end{array}$

$\begin{array}{ll}\text { BIBLIOGRAPHY } & 157\end{array}$

$\begin{array}{ll}\text { INDEX } & 165\end{array}$ 
This page intentionally left blank 


\section{ABOUT THE AUTHORS}

\section{Xavier Pavie}

Xavier Pavie holds Master's Degrees in Management and Philosophy and a Ph.D. in the latter. Xavier has successfully held executive positions in leading companies for 15 years and in 2008 he was appointed Director of the Institute for Strategic Innovation \& Services (ISIS) at ESSEC Business School. He is also research associate at IREPH (Institut Recherche Philosophique) - Université Paris Ouest.

Xavier's publications focus on philosophical approaches to innovation management and more particularly on the notion of performance. He has published several articles and a dozen of books on philosophy and on innovation.

\section{Victor Scholten}

Victor Scholten holds a Ph.D. in Entrepreneurship from Wageningen University. He is Assistant Professor in Technology-Based Entrepreneurship at Delft University of Technology, the Netherlands. Before joining Delft University of Technology in 2007, he held the position of Assistant Professor at Erasmus University in Rotterdam.

His current research interests are in academic spin-out companies, technology transfer to SMEs, responsible innovation and new business venturing, entrepreneurial teams and entrepreneurial networking strategies.

\section{Daphné Carthy}

Daphné Carthy holds a B.A. in International Business from Dublin City University and a Post-Graduate Diploma in International Business Development from Dublin Institute of Technology in Ireland. She is a Research Associate at the Institute for Strategic Innovation and Services (ISIS) at ESSEC Business School. Prior to joining ISIS, she worked as a market 
researcher and consultant in business development and marketing based in Paris and Düsseldorf.

Her current research areas of interest include the integration of responsibility into the innovation process as a strategy for achieving performance objectives. 


\section{ACKNOWLEDGMENTS}

We wish to acknowledge the Institute for Strategic Innovation and Services (ISIS) of ESSEC Business School for helping us to develop the concept of responsible innovation over the past few years and particularly: Prof. Hervé Mathe, Luce Abrate, Simon Paranthoën and Viveka Gidwani.

We are very grateful to the many partners who contributed to enriching the debate on responsible innovation: members of the FAIR project and the Centre Francilien de l'Innovation, notably Michel Daigney, Gaëlle Hin, Doris Kirschner and Serge Gadbois.

Last but not least, we would like to express our gratitude to all students and speakers who took part in the responsible innovation course at ESSEC Business School over the last two years.

Xavier Pavie \& Daphné Carthy

I appreciate the support and discussion I had with colleagues in the department of Values, Technology and Innovation of Delft University of Technology. The thinking and philosophical discussions with Prof. Jeroen van den Hoven and Prof. Ibo van de Poel helped me framing the concept of responsible innovation and translate it to practical value. Also the suggestions and reflections of Prof. Cees van Beers, Dap Hartmann and Patrick van der Duin contributed much to the further understanding of responsible innovation and the opportunities it provides for SMEs.

I also thank Frank O'Connor, Simon O'Rafferty and Merel Claes, when they were at the Ecodesign Centre in Wales, for their valuable leads which were central to the work that we conducted within the KARIM project and led to the inception of the present book.

Finally I wish to thank all the students that raised questions and helped us much in articulating our thoughts and make it understandable for a wider audience. 
The research presented in this book was partly derived from actions undertaken as part of the KARIM (Knowledge Acceleration Responsible Innovation Metanetwork) project. Part of the INTERREG IVB North-West Europe strategic initiatives program, KARIM brings together eight partners from six States of North-West Europe (France, Germany, Great Britain, Ireland, the Netherlands and Switzerland). It aims to improve SME access to technology and innovation support services (in particular those related to responsible innovation projects), thereby boosting North-West Europe's competitiveness. The project's main objectives are to establish a definition of responsible innovation; to facilitate the transfer of knowledge across North-West Europe; to build a strategic network of innovation actors and to provide support for innovation.
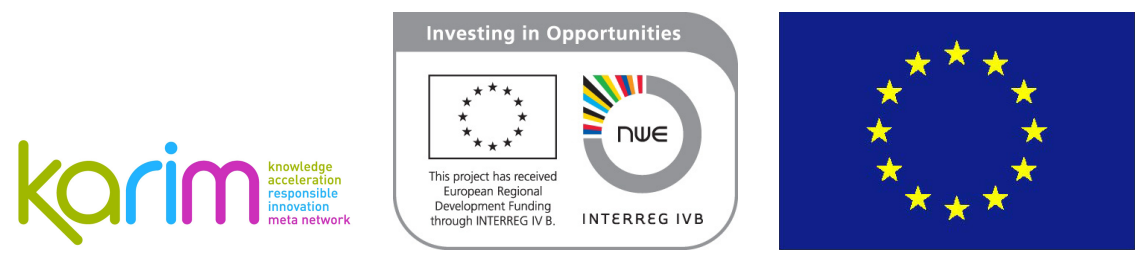


\section{INTRODUCTION}

\section{Understanding and Justifying the Need for Responsibility}

On the 27th September 1962, amidst a context of rapid growth and development driven by a booming plastic industry and the expansion of large petrochemical companies, Rachel Carson published a groundbreaking work in the history of innovation: "Silent Spring." At the time, insect and bacterial infestations were causing vast destruction of crops across the United States, rendering a high proportion of agricultural produce unfit for consumption. Pesticides were eventually introduced as the ultimate solution for saving crops. ${ }^{1}$

A marine biologist and conservationist, Carson made a prediction that the birds pecking in the fields would die from ingesting the pesticides, leading to a silent spring season. Her theories and suggestion for an alternative solution to replace the constant use of pesticides which could prove to be extremely harmful to human health were seen as a nuisance and generated a storm of controversy. Fifty years later, websites still exist maintaining that Carson was wrong. ${ }^{2}$

In this modern day and age her alarm call is as topical as ever. A website of the American right-wing ultraliberal party advocates the free market, the laisser-faire policy, the freedom to use pesticides and set up environmental protection systems - all issues which reflect initial interrogations presented by Carson and Ayn Rand. ${ }^{3}$ At this stage, a sense of unease prevails: How could we ignore the deaths of birds, or even human beings, which will have ingested the pesticides? The question of responsibility at the heart of innovation is now raised. We must innovate, that is a fact, but at what price?

\footnotetext{
${ }^{1}$ Carson, R (1962). Silent Spring. Boston: Houghton Mifflin Harcourt.

${ }^{2}$ http://rachelwaswrong.org/.

${ }^{3}$ Rand, A (1957). Atlas Shrugged. New York: Signet.
} 


\section{When innovation questions our humanity}

There are numerous actors which claim to engage in responsible innovation: Sodexo, Unilever, L'Oréal, etc. Has the term become the new portmanteau word? What is responsible innovation?

In 2009, the first "savior sibling" was born in France. His parents already had a daughter who suffered from a genetic disease and whose cure depended on collecting stem cells from a sibling. The couple therefore, decided to have a second child for this purpose. In this case, instead of asking "should we do this or not?" The question should rather focus on "why and how should we do this?" The decision to conceive a "savior sibling" was discussed in privacy by the couple and with the doctors. Who has the right for such a solution and who hasn't? Is it a question of financial wealth or health system efficiency - in other words, is it solely intended for inhabitants of the northern hemisphere? Is it our wish to select individuals in this way? Does it make sense to give birth to a child in order to save another?

Making, cloning or improving life: this fundamental question is not recent. Humanity's need for progress can be found already in the Greek and Mayan mythologies. Prometheus is the benefactor of mankind who, through the gift of fire, renders man more powerful while also bestowing on him the gift of wisdom, technical knowledge, art and physical speed. Pandora's myth once again refers to the creation of the perfect human being, while her box contained all kinds of ills for man. In the classical period, Lucretius claims that all men, beyond the gods, must reflect perfection.

Science-fiction has continually addressed topics related to the improvement of mankind, its mechanization and biological modification. Today, these are surpassed by the reality of the "savior sibling."

In August 2012, a visually impaired Canadian tourist having dinner in a fast-food restaurant on the Champs-Elysées in Paris was wearing a digital eyewear device. The piece of technology used for filming and sending the data to his brain enabled him to see. The man was evicted by the restaurant's security staff on the grounds that he was violating French privacy laws by filming the inside of the premises. However, this eye gear essentially was an extension of this individual's humanity. This leads us to address the issues surrounding trans-humanism and posthumanism. 


\section{Three contextual dimensions of responsible innovation}

At this stage, three axes of interrogation are being derived to better identify the responsibility of the innovator:

- The environment and ecosystem;

- Technology and politics; and

- The living and its avatars.

These three questions are all linked to one central issue: the individual's spiritual ability, in other words his ability to work his mind and spirit in addressing a specific issue.

\section{- The environment and ecosystem ${ }^{4}$}

World population stood at one billion in the $19^{\text {th }}$ century, two billion at the beginning of the $20^{\text {th }}$ century and six billion at the start of the $21^{\text {st }}$ century. Since 1975, one billion inhabitants are added every 12 years. Yet, the planet is finite: the resources it produces are limited. How will all these individuals manage to feed themselves and live together? The dates of shortage for raw materials currently used consistently in production processes have officially been determined. In 2010, the European Union classified 14 raw materials such as antimony, beryllium and cobalt, as being of critical importance for saving critical supply sources for the industry. All innovations linked to new technologies use rare earth minerals. Individuals campaigning in favor of a policy for photovoltaic cells seem to forget how environmentally harmful it is to produce these, as it draws on these rare earths. The Toyota Prius, a hybrid car which enables lower fuel consumption, also uses these rare minerals. Moreover, the uneven distribution of the latter can potentially lead to major geopolitical issues.

One third of energy is used to produce energy. In 2010, global energy consumption increased by $5 \%$; China becoming the largest consumer. Is it right to criticize a developing country's decision to not make environmental issues and concerns a top priority? Is it right to tell a Chinese man that he can do without a refrigerator? What would be the consequences

\footnotetext{
${ }^{4}$ Pavie, X (2012). Innovation responsable: Stratégie et levier de croissance des organisations. Paris: Eyrolles.
} 
if the households of even half of the 1.3 billion Chinese people were to be fitted with a refrigerator? Greenhouse gas emission rates would naturally increase, contributing further to global warming. From 1996 to 2008, 11 out of 12 years were recorded as the hottest, since 1850. Not forgetting sea pollution or even deforestation, producing billions of tons of $\mathrm{CO}_{2}$ emissions. Out of the 40,000 identified and recorded species, 16,000 are threatened with extinction. This number represents one out of four mammals, one out of three amphibians, two out of three plants and one out of eight birds.

All of these phenomena are complex and human behavior was most likely a contributing factor. The lobbying budget of the oil industry tripled at the Copenhagen Summit! At the same time, some groups claim that all theories surrounding global warming are a pure sham. Very few people know of the International Union for Conservation of Nature. Yet, many hear of the highly publicized views opposing global warming theories.

\section{- Technology and politics}

We, as human beings, have a constant desire to go faster; our innovations are proof of that. Zero Emission Hyper Sonic Transport (ZEHST), the supersonic rocket plane project by European Aeronautic Defence and Space Company N.V. (EADS), could reduce travel time from Paris to Tokyo to just two hours and a half. Airplanes, nowadays, have capacity for 800 people, illustrating our constant search for the infinitely large. At the same time, research is also pushed towards the infinitely small: researchers are now able to work nanotechnologies and nanoparticles.

In parallel, the desire to control and monitor individuals is also on the rise. This is nothing new, as the English philosopher Jeremy Bentham introduced the idea of the Panopticon ${ }^{5}$ in the $18^{\text {th }}$ century; a space organized in such a way that a single man could supervise and control a number of them. Today, 65,000 cameras are continuously filming London and its inhabitants every move and Facebook now represents over one million subscribers.

Eighty types of files are recorded in France, 45 of which are illegal. In recent news, the American government asked Twitter to pass over information and data belonging to the participants of the Occupy Wall Street movement.

${ }^{5}$ Bentham, J and Bozovic, M (1995). The Panopticon Writings, pp. 29-95. London: Verso. 
We are constantly controlled and supervised, through a phenomenon already identified by the French philosopher Michel Foucault in 1975: the notion of "Biopower." We are prescribed vaccines that we must receive, the condoms that we must use, the five fruits and vegetables that we must ingest, the walking time that we must cover every day. This translates into the attempt to create what the German philosopher Herbert Marcuse referred to as the "uni-dimensional man," by imposing a normative ideal, prescribing a way to be and think as well as producing the individual. This also takes us back to Aldous Huxley's premonitions in his famous work "Brave New World" and those of George Orwell's in "1984." This issue is, evidently, intimately linked to innovation and responsibility.

\section{- The living and its avatars}

It is nowadays possible to reconstruct and implant a face, as well as most organs. The neurosciences are accessing the most intimate knowledge into the way the brain works. Cloning animals has now become a reality. We are tipping into a world where we will be able to reproduce the living, or simply repair it, implant it, use it as material for medication. It is even possible to create life from fully inert elements, through biochemistry. Science-fiction is after all late in comparison to all that mankind has achieved and learned to do.

\section{Spiritual capacity, cornerstone for thinking responsible innovation}

The three dimensions presented can only be deployed appropriately through spiritual capacity. The latter, however, is very complex. If we take a look at an illustration of this complexity within an organizational context, we can see that the main concern nowadays is to take care of employees on a personal basis. Programs promoting a healthy work/life balance, aim to essentially protect the employee from an intrusion of professional life into an intimate setting. Once the individual is home, he should no longer have to think about work. This, nonetheless, has another more devious consequence: when the individual finds himself at work, he should not think about his private life. He should focus on the growth of his organization and therefore innovate, at the risk of forgetting about the society he and his firm are operating in. However, who are these innovations intended for? Are they not the very element that should make him responsible as a citizen?

The innovator is not an individual like any other. He has the ability, through his innovations, to change the face of the world, whether on a small 
or large scale. Consequently, the work of innovation cannot limit itself to the professional sphere. It is an intimate process continually at work within the innovator, at all moments and all occasions. In this sense, it is therefore not favorable to create a clear separation between the innovator's private and professional life.

We cannot foresee the consequences of innovation or the impact of the launch within a new context. The issue does not concern our ability to do something, but rather our willingness (or lack thereof) to do it. An improved knowledge base regarding the living, along with a decreasing influence from the Church, which once prohibited any intervention on the living means that we are now willing to take risks and experiment more, we are playing at alchemy.

What is the solution to guarantee a responsible innovation? The answer can be found in Winnie the Pooh, which begins as follows:

"Here is Edward Bear, coming downstairs now, bump, bump, bump, on the back of his head, behind Christopher Robin. It is, as far as he knows, the only way of coming downstairs, but sometimes he feels that there really is another way, if only he could stop bumping for a moment and think of it." ${ }^{6}$

Christopher Robin could take his bear in his arms or jump from the top to reach the bottom of the stairs. However, he prefers to come down the stairs by letting Edward Bear's head bump off each step, in the same way that we hit the planet with our actions.

\section{Doing things, differently}

It is important to understand that we are not trying to undermine innovation. On the contrary, remaining competitive is absolutely essential, along with making profit in order to survive and keep investing. We have to keep "coming downstairs," but can we do so differently? This is the very essence of responsible innovation. How can we do things differently, and still do them as well?

We are not talking here of social or societal innovation, which would, for instance, consist of helping the poor or the disabled. Responsible innovation concerns innovation in the broad sense, which distinguishes it clearly from an organization's corporate social responsibility (CSR) or sustainable development policy.

${ }^{6}$ Milne, AA (1926). Winnie-the-Pooh. London: Methuen \& Co. Ltd. 